\title{
Biochemical characterization and regulation of cardiolipin synthase in Saccharomyces cerevisiae
}

\author{
Katherine T. Tamai and Miriam L. Greenberg \\ Department of Biological Chemistry, The University of Michigan, Ann Arbor, MI (U.S.A.)
}

(Reccived 12 April 1990)

Key words: Cardiolipin synthase; ( $S$. cerevisiae)

Cardiolipin (CL) synthase activity was characterized in mitochondrial extracts of the yeast Saccharomyces cerevisiae and was shown for the first time to utilize CDP-diacylglycerol as a substrate. $\mathrm{CL}$ synthase exhibited a pH optimum of 9.0. Maximal activity was obtained in the presence of $20 \mathrm{mM}$ magnesium with a Triton X-100: phospholipid ratio of 1:1. The apparent $K_{\mathrm{m}}$ values for phosphatidylglycerol and CDP-diacylglycerol were $1 \mathrm{mM}$ and $36 \mu \mathrm{M}$, respectively. $\mathrm{CL}$ synthase activity was maximal at $45^{\circ} \mathrm{C}$ and heat inactivation studies showed that the enzyme retained greater than $75 \%$ of its activity at temperatures up to $55^{\circ} \mathrm{C}$. To study the regulation of $\mathrm{CL}$ synthase, the enzyme was assayed in cells grown under conditions known to affect general phospholipid synthesis. Unlike many phospholipid biosynthetic enzymes including PGP synthase, which catalyzes the initial step in CL biosynthesis, CL synthase was not repressed in cells grown in the presence of the phospholipid precursor inositol. Detailed procedures for the enzymatic synthesis of ${ }_{32}$ P-labelled substrates are described.

\section{Introduction}

Cardiolipin (CL) is an anionic phospholipid found in prokaryotic cells [1] and in the inner mitochondrial membrane of eukaryotic cells [2,3]. Kornberg and coworkers [4-6] have shown that the anionic phospholipids CL and phosphatidylglycerol (PG) play an important role in DNA replication in $E$. coli by facilitating the ADP-ATP exchange reaction of dnaA protein. In yeast, $C L$ is required for cytochrome oxidase activity $[7,8]$ and $\mathrm{CL}$ and/or PG may be involved in translocation of proteins across the mitochondrial membrane $[9,10]$. Additionally, $C L$ has been reported to be a potent effector of cytochrome $P-450_{\text {scc }}$-dependent cholesterol side chain cleavage activity in bovine adrenal mitochondria [11,12].

The biosynthesis of $\mathrm{CL}$ involves three sequential reactions [13-16]. The first two steps (reactions 1 and 2) are similar in eukaryotes and prokaryotes. However, mammalian cells utilize CDP-diacylglycerol in the synthesis of CL (reaction 3), while in bacteria two molecules of PG condense to form CL (reaction 4) [17]. (1) glycerol 3-phosphate + CDP-diacylglycerol $\rightarrow$ PGP (phosphatidylglycerolphosphate) + CMP

Correspondence: M.L. Greenberg, Dept. Biological Chemistry, The University of Michigan, Ann Arbor, MI, 48709-0606, U.S.A.
(2) $\mathrm{PGP}+\mathrm{H}_{2} \mathrm{O} \rightarrow \mathrm{PG}$ (phosphatidylglycerol) $+\mathbf{P}_{\mathrm{i}}$

(3) $\mathrm{PG}+\mathrm{CDP}$-diacylglycerol $\rightarrow \mathrm{CL}+\mathrm{CMP}$

(4) $2 \mathrm{PG} \rightarrow \mathrm{CL}+$ glycerol

Substantial information on the synthesis of the major anionic phospholipids, PG and CL, has been obtained in $E$. coli. The enzymes that catalyze the synthesis of CL have been characterized biochemically and the genes encoding these enzymes have been cloned. To determine whether anionic phospholipids are essential for cell viability, gene disruption experiments were performed [18-21]. Disruption of the cls (CL synthase) gene is not lethal, but strains disrupted in $c l s$ continue to make $\mathrm{CL}$ (presumably via another enzyme, phosphatidylserine synthase). However, strains bearing a disruption of the pys $A$ (PGP synthase) gene are inviable. These data suggest that in $E$. coli, the anionic phospholipids PG and/or CL are required for viability.

Much less is known about the enzymes for $\mathrm{CL}$ synthesis in eukaryotes. CL biosynthetic enzymes have been only partially purified in a few mammalian systems [22-24]; however, nothing is known about the regulation of these enzymes or the genes that encode them. By studying the enzymes that catalyze the formation of $\mathrm{CL}$ and isolating their respective genes, we can gain insight into the function of $\mathrm{CL}$ in eukaryotic organisms. Because yeast is more amenable to combined genetic, molecular and biochemical analysis than any other eukaryote, it is an excellent system in which to study $C L$ synthesis and function. 
The CL synthase reaction has never been analyzed in yeast. Thus the correct pathway for CL synthesis in this organism has not been previously determined. Although phospholipid synthesis in yeast is generally carried out by enzymes common to higher eukaryotes, at least one exception has been observed. Phosphatidylserine is synthesized in yeast and bacteria from CDP-diacylglycerol and serine, while in higher eukaryotes PS is synthesized by an exchange reaction between phosphatidylethanolamine and serine [14-16]. We initiated this study of the yeast CL synthase in order to characterize the enzyme biochemically and to determine whether the reaction followed the prokaryotic or eukaryotic route. Characterization of the enzyme, furthermore, is essential for further molecular analysis of the gene that encodes it.

Yeast CL synthase activity was undetectable under assay conditions described for the bacterial and mammalian enzymes [18,24]. Furthermore, these assays relied on preparation of the substrate $\left[{ }^{14} \mathrm{C}\right] \mathrm{PG}$, which is costly and less efficient than the ${ }^{32} \mathrm{P}$-labelled substrates used in our assays. In this report, we describe the biochemical characterization of yeast $C L$ synthase and demonstrate for the first time that CDP-diacylglycerol is a substrate in the reaction. We also present detailed procedures for the preparation of both ${ }^{32} \mathrm{P}$-labelled substrates PG and CDP-diacylglycerol. Finally, we show that, unlike most phospholipid biosynthetic enzymes (including PGP synthase which catalyzes the initial reaction in CL biosynthesis), CL synthase expression is not repressed by the phospholipid precursor inositol.

\section{Materials and Methods}

\section{Materials}

Most of the chemicals including dioleoylglycerol, dioleoyl phosphatidic acid, dioleoyl phosphatidylglycerol and E. coli cardiolipin were obtained from Sigma Chemical. $\left[\gamma-{ }^{32}\right.$ P]ATP was purchased from Dupont, New England Nuclear Research Products. Diacylglycerol kinase was obtained from Lipidex (Westfield, NJ). Egg CDP-diacylglycerol was purchased from Life Science Resources (Milwaukee, WI). Silica-gel 60 thinlayer plates $(0.25 \mathrm{~mm})$ were the products of $\mathrm{E}$. Merck (Darmstadt, F.R.G.). Kodak XAR-5 film was used for autoradiography in conjunction with an intensifying screen (Dupont Lightening Plus). Ready Safe scintillation cocktail was purchased from Beckman Instruments, Bio-safe II was purchased from Research Products International Corp. and BetaMax was obtained from ICN Schwartz/Mann.

Bacterial strains, growth conditions and preparation of cell fractions

An E. coli K12 strain DH1/pCD100 which overproduces CDP-diacylglycerol synthase 53-fold [25] was the gift of Dr. Christian Raetz, Merck, Sharp and Dohme
(Rahway, NJ) and was grown in LB medium plus 30 $\mu \mathrm{g} / \mathrm{ml}$ chloramphenicol at $30^{\circ} \mathrm{C}$. An $E$. coli $\mathrm{CL}$ synthase mutant HW55 [26] was the gift of Dr. Burton Tropp, Queens College, Flushing, New York and a plasmid containing the PGP synthase gene, pPGL3008 [27] used to transform strain HW55 was the gift of Dr. William Dowhan, University of Texas, Houston, Texas. Strain HW55/pPGL3008 was grown in LB medium plus $12.5 \mu \mathrm{g} / \mathrm{ml}$ tetracycline at $37^{\circ} \mathrm{C}$. Crude extracts of cells were prepared by three passages through a French press after suspension in $100 \mathrm{mM}$ Tris- $\mathrm{HCl}(\mathrm{pH} \mathrm{7.5)}$; unbroken cells were removed by centrifugation at 3000 $\times g$. The membrane and cytosolic fractions were then separated by centrifugation at $100000 \times g$ for $90 \mathrm{~min}$ and the supernatant was discarded. The membrane fraction was resuspended in $100 \mathrm{mM}$ Tris- $\mathrm{HCl}(\mathrm{pH} \mathrm{7.5)}$ and stored at $-80^{\circ} \mathrm{C}$.

Yeast strains, growth conditions and preparation of cell fractions

The wild type strains used in this study were D273-

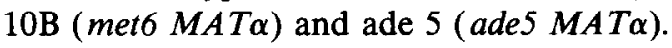

For the enzyme characterization studies, strain D273-10B was grown at $30^{\circ} \mathrm{C}$ in minimal media containing $0.27 \%$ vitamin-free yeast base (as described in the Difco Manual omitting dextrose, histidine, methionine and tryptophan), vitamins [28], 3\% glycerol, $0.95 \%$ ethanol and $0.002 \%$ methionine, using the fermentation facility of the Department of Biological Chemistry, University of Michigan, Ann Arbor. The cells were grown to log phase and harvested using a Sharples centrifuge and the cell paste was stored at $-80^{\circ} \mathrm{C}$. Mitochondria were isolated essentially as described by Carman and Belunis [29]. Approx. $75 \mathrm{~g}$ of cells were washed and resuspended in $100 \mathrm{ml}$ of buffer containing $50 \mathrm{mM}$ Tris- $\mathrm{HCl}$ (pH 7.5), $1 \mathrm{mM}$ EDTA, $0.3 \mathrm{M}$ sucrose and 10 $\mathrm{mM}$ 2-mercaptoethanol. The cell suspension was mixed with $300 \mathrm{~g}$ of pre-chilled glass beads and disrupted by homogenization in a Biospec Products Bead Beater for five 1-min bursts, with a 4-min pause between bursts. The homogenate was then centrifuged twice at $4000 \times g$ for $10 \mathrm{~min}$ in a GSA rotor to remove the glass beads and unbroken cells. The supernatant was centrifuged at $27000 \times \mathrm{g}$ for $10 \mathrm{~min}$ in a Sorvall SS34 rotor to pellet mitochondria. The pellet was washed twice in homogenization buffer and then resuspended in buffer containing $50 \mathrm{mM}$ Tris- $\mathrm{HCl}(\mathrm{pH} 7.5), 10 \mathrm{mM}$ 2-mercaptoethanol and $20 \%$ glycerol and stored at $-80^{\circ} \mathrm{C}$.

For the regulation studies, ade 5 was grown at $30^{\circ} \mathrm{C}$ in 21 Erlenmeyer flasks in minimal media as described above, except that $0.15 \mathrm{mM}$ adenine was added for growth and $2 \%$ glucose replaced $3 \%$ glycerol $/ 0.95 \%$ ethanol as the carbon source. In addition, $75 \mu \mathrm{M}$ inositol was added where indicated. Cells were grown to log phase, harvested by centrifugation, and washed in buffer containing $50 \mathrm{mM}$ Tris- $\mathrm{HCl}(\mathrm{pH} 7.5), 10 \mathrm{mM}$ 
2-mercaptoethanol and $20 \%$ glycerol. The cell pellets were then resuspended at $1 \mathrm{~g}$ wet weight of cells per ml in the same buffer and mitochondria were isolated as described by Greenberg et al [30]. Cells were broken open by vortexing with pre-chilled glass beads for five 1-min bursts, cooling cells on ice between bursts. Homogenates were then centrifuged for $5 \mathrm{~min}$ in a Sorvall SS34 rotor at $3000 \times g$ and the pellet discarded; the supernatant was centrifuged twice more, each time discarding the pellet. The remaining supernatant was then centrifuged for $10 \mathrm{~min}$ at $27000 \times \mathrm{g}$ to pellet mitochondria, washed twice and resuspended in homogenization buffer, and stored at $-80^{\circ} \mathrm{C}$.
Synthesis of $\left[{ }^{32} P\right]$ phosphatidylglycerol

$\left[{ }^{32} \mathrm{P}\right]$ Phosphatidylglycerol (PG) was synthesized enzymatically from $\left[\gamma-{ }^{32} \mathrm{P}\right] \mathrm{ATP}$, dioleoylglycerol, CTP and glycerol 3-phosphate in three steps (Fig. 1). A method for labelling PG with ${ }^{14} \mathrm{C}$ has been described $[18,31]$. However, we chose to prepare $\left[{ }^{32} \mathrm{P}\right] \mathrm{PG}$ because it is at least 200 -fold cheaper than $\left[{ }^{14} \mathrm{C}\right] \mathrm{PG}$ and shortens autoradiographic exposure time significantly. First, high specific activity $\left[{ }^{32} \mathrm{P}\right]$ phosphatidic acid was synthesized from $\left[\gamma^{32}\right.$ P $]$ ATP and dioleoylglycerol by diacylglycerol kinase as described by Walsh and Bell [32] with minor modifications. The $100 \mu 1$ reaction contained $51 \mathrm{mM}$ octyl glucoside, $1 \mathrm{mM}$ bovine cardiolipin, $60 \mathrm{mM}$ im-<smiles>[R]C(=O)OCC(CO)OC([2H])=O</smiles><smiles></smiles>

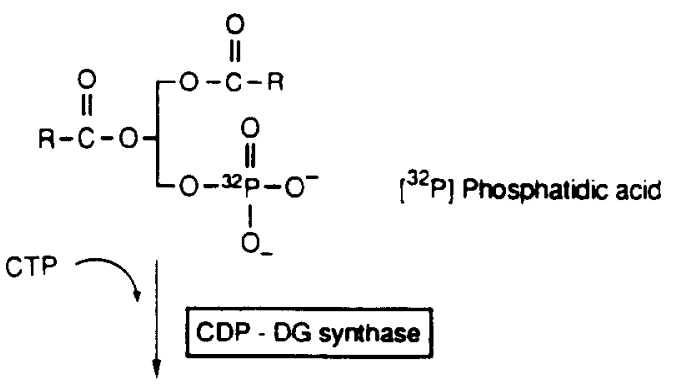

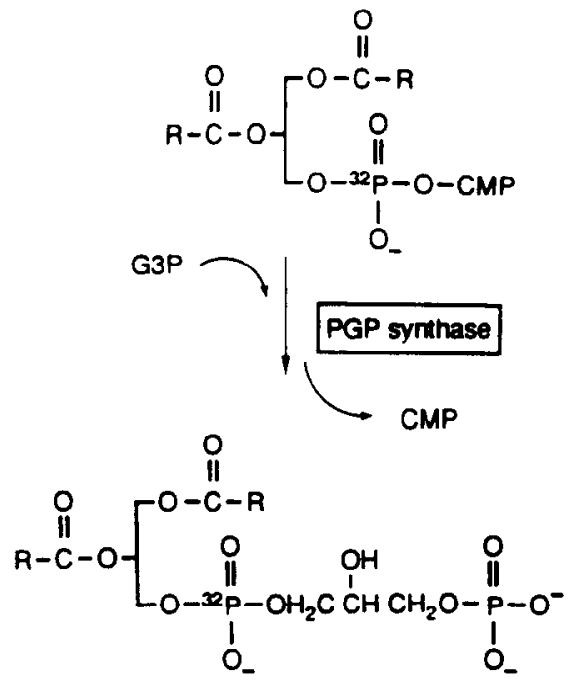

12PIPGP $\left[^{32} \mathrm{P}\right] \mathrm{CDP}-\mathrm{DG}$

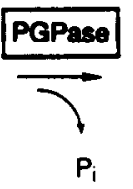<smiles>[2H]C(=O)OCCOP(=O)([O-])OCC(O)CO</smiles>

P2PIPG $^{32}$

Fig. 1. Reaction scheme for the synthesis of $\left[{ }^{32} \mathrm{P}\right] \mathrm{PG}$. [ $\left.{ }^{32} \mathrm{P}\right] \mathrm{PG}$ was synthesized from [ $\left.\gamma^{32} \mathrm{P}\right] \mathrm{ATP}$, dioleoylglycerol, CTP and glycerol 3-phosphate as described. 
idazole (pH 6.6), $50 \mathrm{mM} \mathrm{NaCl}, 12.5 \mathrm{mM} \mathrm{MgCl}_{2}, 1 \mathrm{mM}$ EGTA, $0.3 \mathrm{mM}$ DTPA, $2 \mathrm{mM}$ DTT, $2 \mathrm{mM}$ dioleoylglycerol, $50 \mu \mathrm{M} \mathrm{Na}{ }_{2} \mathrm{ATP}(2500 \mathrm{Ci} / \mathrm{mol})$ and $50 \mu \mathrm{g}$ of diacylglycerol kinase. The reaction proceeded for $1 \mathrm{~h}$ at room temperature.

Next, to convert $\left[{ }^{32} \mathrm{P}\right]$ phosphatidic acid to $\left[{ }^{32} \mathrm{P}\right]-$ CDP-diacylglycerol, the diacylglycerol kinase reaction was diluted to a final volume of $1 \mathrm{ml}$ consisting of 0.1 $M$ potassium phosphate ( $\mathrm{pH} 7.4), 10 \mathrm{mM} \mathrm{MgCl}_{2}, 3.2$ $\mathrm{mM}$ Triton X-100, $0.25 \mathrm{mM}$ DTT, $5 \mathrm{mM}$ CTP and 250 $\mu \mathrm{g}$ of crude membrane protein from strain DH1pCD100 which overproduces CDP-diacylglycerol synthase 53-fold [25]. Cold dioleoyl phosphatidic acid was omitted from the reaction to maintain a high specific activity. The reaction was incubated at $30^{\circ} \mathrm{C}$ for $1 \mathrm{~h}$.

Finally, $\left[{ }^{32} \mathrm{P}\right] \mathrm{PG}$ was synthesized from $\left[{ }^{32} \mathrm{P}\right] \mathrm{CDP}$-diacylglycerol and glycerol 3-phosphate by PGP synthase and PGP phosphatase from an $E$. coli strain HW55/pPGL3008 which overproduced PGP synthase greater than 50-fold (unpublished data). This strain was constructed by transforming an $E$. coli $C L$ synthase mutant HW55 [26] with a plasmid pPGL3008 containing the PGP synthase gene [27]. High endogenous PGP phosphatase levels eliminated the need to overproduce this enzyme, while the CL synthase mutation minimized the conversion of $\left[{ }^{32} \mathrm{P}\right] \mathrm{PG}$ to $\left[{ }^{32} \mathrm{P}\right] \mathrm{CL}$. The reaction components necessary for PGP synthase activity [33] with modifications were added directly to the CDP-diacylglycerol synthase reaction mixture increasing the total volume to $5 \mathrm{ml}$. The reaction contained $0.1 \mathrm{M}$ Tris- $\mathrm{HCl}$ ( $\mathrm{pH} 8.0$ ), $0.1 \mathrm{M} \mathrm{MgCl}_{2}, 5 \mathrm{mM}$ glycerol 3phosphate and $2.2 \mathrm{mg}$ of crude membrane protein from strain HW55/pPGL3008. Following incubation at $37^{\circ} \mathrm{C}$ for $4 \mathrm{~h}$, the ${ }^{32} \mathrm{P}$-labelled lipid products were separated from unreacted $\left[\gamma^{32} \mathrm{P}\right]$ ATP by the addition of $1 \mathrm{ml} 0.1$ $\mathrm{M} \mathrm{HCl}$ in methanol and $5 \mathrm{ml}$ chloroform and further purified by Silica-gel 60 thin-layer chromatography in chloroform/methanol/water $(65: 25: 8, \mathrm{v} / \mathrm{v})$ [31]. The chromatogram was then briefly exposed to X-ray film, and the $\left.{ }^{32} \mathrm{P}\right] \mathrm{PG}$ was identified by comigration with authentic dioleoyl PG, then scraped and eluted from the silica-gel with chloroform/ $0.1 \mathrm{M} \mathrm{HCl}$ in methanol/ water $(1: 1: 0.9, \mathrm{v} / \mathrm{v})$ [34]. Typically, the conversion of $\left[\gamma-{ }^{32} \mathrm{P}\right] \mathrm{ATP}$ to $\left[{ }^{32} \mathrm{P}\right] \mathrm{PG}$ was $40-50 \%$.

\section{Synthesis of $\left.{ }^{32} P\right] C D P$-diacylglycerol}

$\left[{ }^{32} \mathrm{P}\right] \mathrm{CDP}$-diacylglycerol labelled in the phosphatidyl moiety was synthesized enzymatically in two reactions. High specific activity $\left[{ }^{32} \mathrm{P}\right]$ phosphatidic acid was synthesized exactly as described above. The diacylglycerol kinase reaction was then stopped with $100 \mu \mathrm{l}$ of $0.1 \mathrm{M} \mathrm{HCl}$ in methanol and $\left[{ }^{32} \mathrm{P}\right]$ phosphatidic acid was extracted by the addition of $0.5 \mathrm{ml}$ chloroform and 0.5 $\mathrm{ml}$ of $1 \mathrm{M} \mathrm{NaCl}$. An aliquot of the chloroform layer was dried and counted in a Beckman Scintillation Counter. The specific radioactivity of the $\left[{ }^{32} \mathrm{P}\right]$ phosphatidic acid was adjusted to $10000 \mathrm{cpm} / \mathrm{nmol}$ with cold dioleoyl phosphatidic acid, and $\left[^{32} \mathrm{P}\right]$ phosphatidic acid was converted to $\left[{ }^{32} \mathrm{P}\right] \mathrm{CDP}$-diacylglycerol essentially as described above except that the final phosphatidic acid concentration was $1 \mathrm{mM}$. After $1 \mathrm{~h}$ at $30^{\circ} \mathrm{C}$, the reaction was stopped with $0.5 \mathrm{ml}$ of $0.1 \mathrm{M} \mathrm{HCl}$ in methanol and lipids were extracted with $1 \mathrm{ml}$ chloroform. The chloroform layer was then spotted onto a Silica-gel 60 thin-layer chromatography plate and run in chloroform/methanol/glacial acetic acid $(65: 25: 8, \mathrm{v} / \mathrm{v})$. The chromatogram was briefly exposed to X-ray film and the $\left[{ }^{32} \mathrm{P}\right] \mathrm{CDP}$-diacylglycerol product was identified by comigration with authentic CDP-diacylglycerol. The band was scraped and eluted from silica-gel with chloroform $/ 0.1 \mathrm{M} \mathrm{HCl}$ in methanol/water $(1: 1: 0.9, \mathrm{v} / \mathrm{v})$. The conversion of $\left[{ }^{32} \mathrm{P}\right]$ phosphatidic acid to $\left[{ }^{32} \mathrm{P}\right] \mathrm{CDP}-$ diacylglycerol under these conditions was approx. $60 \%$.

\section{$C L$ synthase enzyme assay}

Protein concentration was determined by the method of Bradford [35] using bovine serum albumin as the standard. An aliquot of high specific activity $\left[{ }^{32} \mathrm{PJPG}\right.$ in chloroform was dried under $\mathrm{N}_{2}$ and the specific radioactivity was adjusted to $5000-10000 \mathrm{cpm} / \mathrm{nmol}$ with cold dioleoyl phosphatidylglycerol in water and sonicated. CL synthase activity was then measured at $45^{\circ} \mathrm{C}$ in mitochondrial extracts in the presence of $100 \mathrm{mM}$ Tris- $\mathrm{HCl}$ (pH 9.0), $20 \mathrm{mM} \mathrm{MgCl}{ }_{2}, 0.1 \mathrm{mM}$ CDP-diacylglycerol, $0.5 \mathrm{mM}\left[{ }^{32} \mathrm{P}\right] \mathrm{PG}$ and $0.6 \mathrm{mM}$ Triton X-100 in a total volume of $100 \mu \mathrm{l}$. After $20 \mathrm{~min}$, the reaction was stopped with $0.5 \mathrm{ml} 0.1 \mathrm{M} \mathrm{HCl}$ in methanol and lipids were extracted with $1 \mathrm{ml}$ chloroform and $1.5 \mathrm{ml} 1 \mathrm{M}$ $\mathrm{MgCl}_{2}$. The samples were then vortexed and the phases separated by centrifugation for $3 \mathrm{~min}$ at $100 \times \mathrm{g}$. A 0.5 $\mathrm{ml}$ aliquot of the chloroform layer was transferred to a $1.5 \mathrm{ml}$ Eppendorf tube and evaporated in air. The samples were rinsed with $100 \mu 1$ of chloroform and evaporated again, and then spotted onto a Silica-gel 60 TLC plate by rinsing the tubes four times with $12 \mu \mathrm{l}$ of chloroform. The chromatogram was run in chloroform/ methanol/glacial acetic acid $(65: 25: 8, \mathrm{v} / \mathrm{v})$ and then exposed to $\mathrm{X}$-ray film. The $\left[{ }^{32} \mathrm{P}\right] \mathrm{CL}$ product was identified by alkaline hydrolysis as described below; however, for routine assays, $\left[{ }^{32} \mathrm{P}\right] \mathrm{CL}$ was identified by comigration with $E$. coli $\mathrm{CL}$, and the spots were then scraped into scintillation vials with $0.5 \mathrm{ml}$ water and $5 \mathrm{ml}$ Ready Safe or Biosafe II and counted in a Beckman Scintillation Counter. The assay was linear with respect to time (10-30 min) and protein concentration $(10-100 \mu \mathrm{g})$. A unit (U) of enzyme activity is defined as the number of nmol of product formed per min under the assay conditions described above. The specific activity is defined as units per $\mathrm{mg}$ of protein. A complete reaction mixture stopped at time zero was included with each assay and each sample was run in triplicate. 


\section{Deacylation of phospholipids}

To identify substrates and products, ${ }^{32} \mathrm{P}$-labelled phospholipids were subjected to deacylation by mild alkaline hydrolysis as described by Davidson and Stanacev [36]. Samples and standards in chloroform were dried down under a stream of $\mathrm{N}_{2}$ and resuspended in $2.5 \mathrm{ml}$ of chloroform/methanol $(1: 1, \mathrm{v} / \mathrm{v})$. The samples were then made alkaline by the addition of 50 $\mu 1$ of $4 \mathrm{M} \mathrm{NaOH}$. After $10 \mathrm{~min}$ at room temperature, the reactions were stopped with $250 \mathrm{mg}$ of Dowex AG-50W-X4 (acid form) and immediately extracted with $1 \mathrm{ml}$ of water. After centrifugation to separate the phases, the supernatants were saved, and the samples were re-extracted with another $\mathrm{ml}$ of water. The water extracts were combined, made alkaline by adding several drops of $0.5 \mathrm{M} \mathrm{NH}_{4} \mathrm{OH}$ (tested with $\mathrm{pH}$ paper), and evaporated to dryness in a Savant Speed Vac Concentrator. The samples were then resuspended in 5-10 $\mu \mathrm{l}$ of water and spotted in duplicate onto Whatman No. 1 paper chromatograms. The two chromatograms were run in different solvents: isopropanol/water/ammonia $(7: 2: 1, \mathrm{v} / \mathrm{v})[37]$ and $1 \mathrm{M}$ ammonium acetate $(\mathrm{pH}$ 7.4)/absolute ethanol $(35: 65, \mathrm{v} / \mathrm{v})$ [38]. The standards were then identified by the Hanes and Isherwood spray [39] which identifies water-soluble phosphate-containing compounds. The results in Fig. 7 show that the correct ${ }^{32} \mathrm{P}$-labelled lipids were synthesized and that the ${ }^{32} \mathrm{P}$ labelled product from a CL synthase assay is CL.

\section{Results}

\section{Properties of yeast $C L$ synthase}

CL synthase activity was measured in $100 \mathrm{mM}$ Tris buffer from pH 7.0 to 10.0. A pH optimum of 9.0 was observed (Fig. 2). The effect of various divalent cations was determined and maximal activity was obtained in the presence of $20 \mathrm{mM}$ magnesium ions. Manganese,

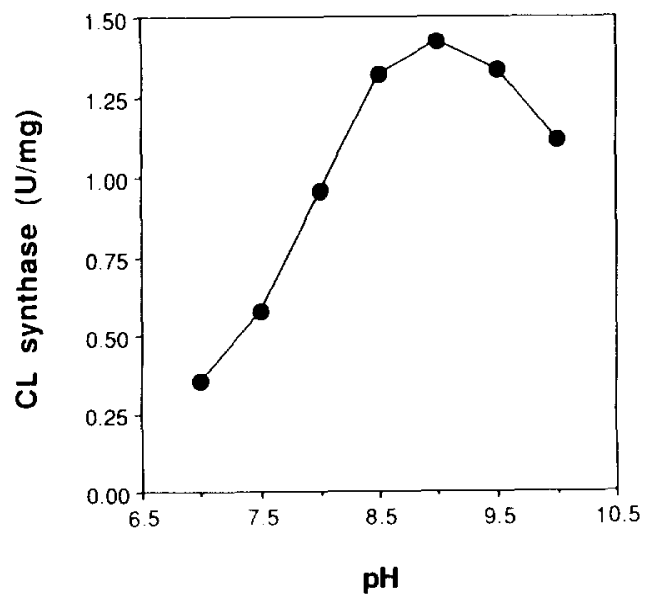

Fig. 2. Effect of $\mathrm{pH}$ on $\mathrm{CL}$ synthase activity. $\mathrm{CL}$ synthase activity was measured in $100 \mathrm{mM}$ Tris buffer at the indicated $\mathrm{pH}$ values as described.

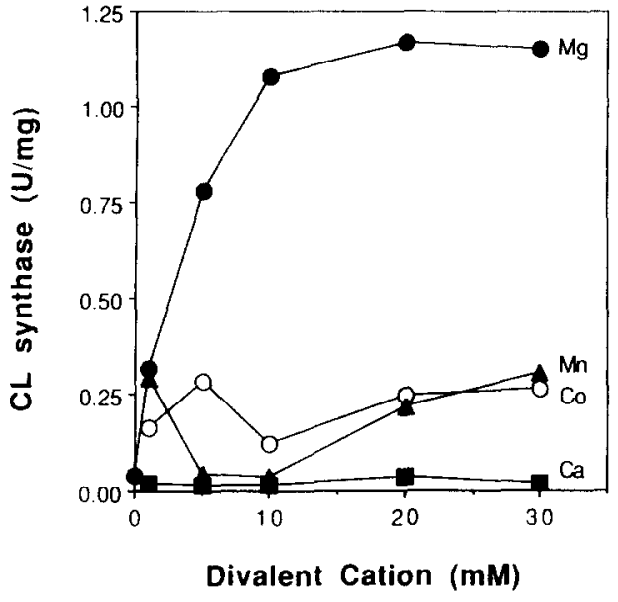

Fig. 3. Effect of divalent cations on $C L$ synthase activity. CL synthase activity was measured with the indicated concentrations of divalent cation as described.

cobalt and calcium ions had little or no effect on CL synthase activity (Fig. 3). The concentration of Triton $\mathrm{X}-100$ was varied to determine the optimal ratio of detergent to phospholipid substrate. Phospholipid concentrations used in these experiments were $0.1 \mathrm{mM}$ CDP-diacylglycerol and $0.5 \mathrm{mM}$ PG. First, the ratio of Triton X-10 to CDP-diacylglycerol was kept constant while varying the ratio of Triton $X-100$ to $P G$. An optimal ratio of $1: 1$ Triton $X-100$ to $P G$ was found (data not shown). Next, the ratio of Triton $X-100$ to CDP-diacylglycerol was varied while maintaining the Triton $X-100: P G$ ratio at $1: 1$. An optimal ratio of $1: 1$ Triton X-100 to CDP-diacylglycerol was found (data not shown). Finally, the concentration of Triton X-100 was varied to determine the optimal ratio of detergent to total phospholipid (Fig. 4). Activity appeared to plateau at ratios of $1: 1$ to $5: 1$. However, at Triton $\mathrm{X}-100$ : phospholipid ratios greater than $10: 1$, CL syn-

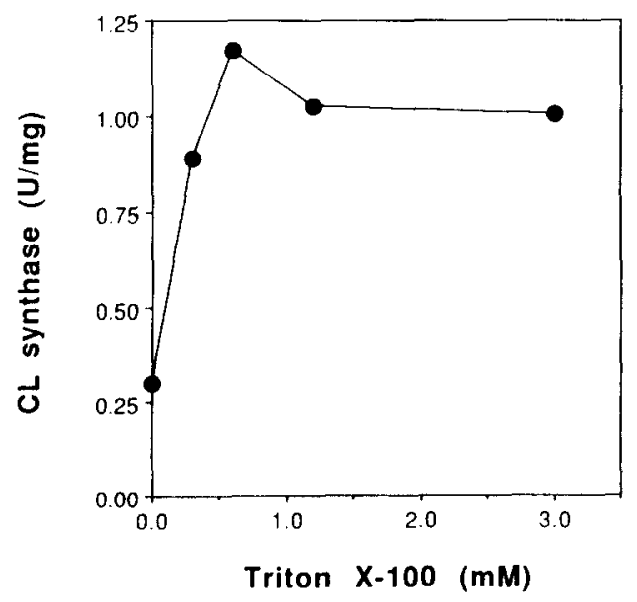

Fig. 4. Effect of Triton X-100 on CL synthase activity. CL synthase activity was measured with the indicated concentrations of Triton $\mathrm{X}-100$ in the presence of $0.1 \mathrm{mM}$ CDP-diacylglycerol and $0.5 \mathrm{mM} \mathrm{PG}$ as described. 

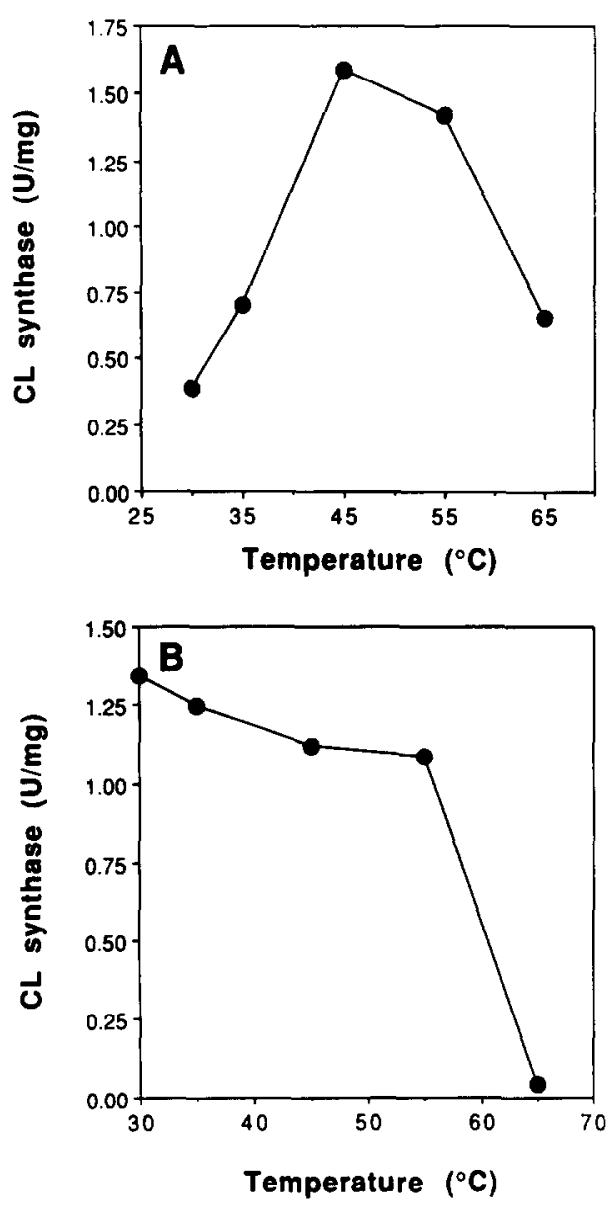

Fig. 5. Effect of temperature on CL synthase activity. (A) CL synthase activity was measured at the indicated temperatures as described. (B) Mitochondrial extracts were incubated for $20 \mathrm{~min}$ at the indicated temperatures in a controlled temperature water bath. The samples were then placed on ice for $20 \mathrm{~min}$, reaction components added and CL synthase activity measured as described.

thase was inhibited (data not shown), suggesting that the enzyme followed substrate dilution kinetics.

$\mathrm{CL}$ synthase activity was measured from 30 to $65^{\circ} \mathrm{C}$ in a controlled temperature water bath, and optimal activity was observed at $45^{\circ} \mathrm{C}$ (Fig. 5). Thermal stability analysis of $\mathrm{CL}$ synthase indicated that the enzyme is stable to $55^{\circ} \mathrm{C}$. (Fig. 5B).

Saturation kinetics were displayed with respect to both phospholipid substrates PG and CDP-diacylglycerol. Reciprocal plots show apparent $K_{\mathrm{m}}$ values of $1 \mathrm{mM}$ and $36 \mu \mathrm{M}$ for PG and CDP-diacylglycerol, respectively (Fig. 6). However, at high concentrations, both phospholipid substrates PG and CDP-diacylglycerol were inhibitory: concentrations of $P G$ and CDP-diacylglycerol greater than $0.65 \mathrm{mM}$ and $0.10 \mathrm{mM}$, respectively, inhibited $C L$ synthase activity.

Utilization of CDP-diacylglycerol as a substrate by yeast CL synthase.

Direct proof that CDP-diacylglycerol is a substrate for $\mathrm{CL}$ synthase is shown in Figs. 7 and 8. Enzyme assays were performed as described using as labelled substrates either $\left[{ }^{32} \mathrm{P}\right] \mathrm{CDP}$-diacylglycerol labelled in the phosphatidyl moiety, or $\left[{ }^{32} \mathrm{P}\right] \mathrm{PG}$. Lipids were extracted and chromatographed as described and in both cases a unique ${ }^{32} \mathrm{P}$-labelled spot comigrating with an $E$. coli $\mathrm{CL}$ standard was observed (Fig. 7). This ${ }^{32} \mathrm{P}$-labelled lipid and phospholipid standards were subjected to mild alkaline hydrolysis and chromatographed. The deacylated product of this lipid comigrated with the carbon backbone of the CL standard (Fig. 8). Incorporation of the ${ }^{32} \mathrm{P}$ label from CDP-diacylglycerol into $\mathrm{CL}$ demonstrates directly that yeast $\mathrm{CL}$ synthase utilizes CDP-diacylglycerol as a substrate.

\section{Regulation of $C L$ synthase}

To study the regulation of CL synthase, wild type cells were grown under conditions known to affect general phospholipid synthesis. Cells were grown in the presence or absence of inositol, a phospholipid pre-
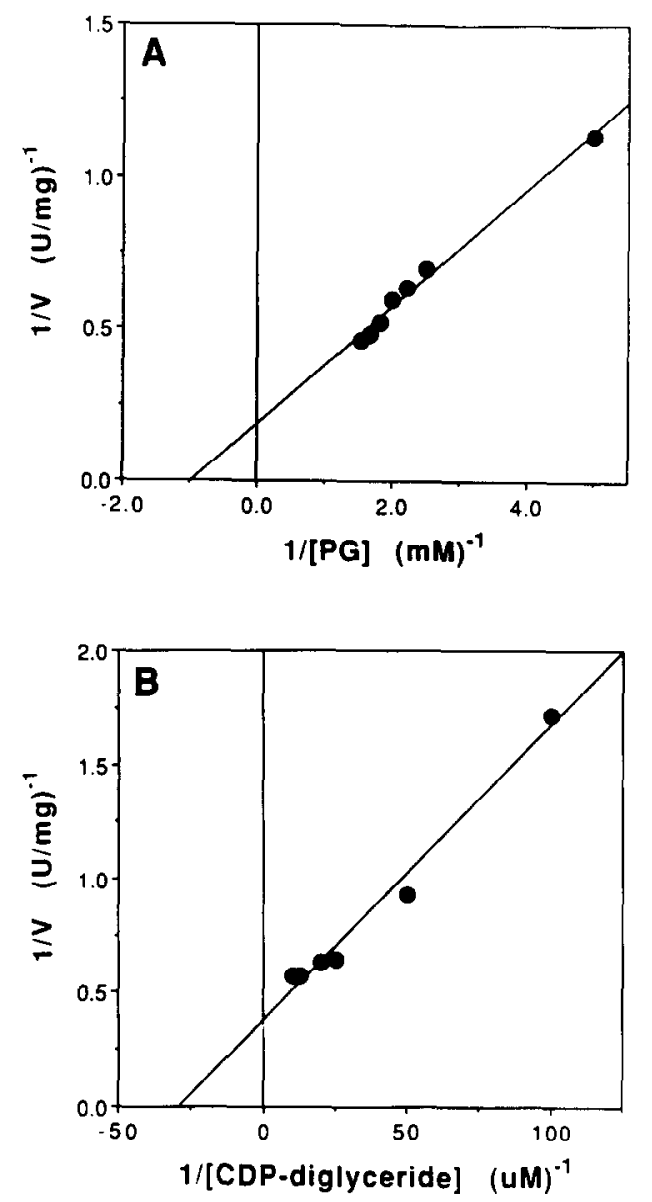

Fig. 6. Dependence of $\mathrm{CL}$ synthase activity on the concentration of $\mathrm{PG}$ and CDP-diacylglycerol. (A) The data are plotted as $1 / \mathrm{V}(\mathrm{U} / \mathrm{mg})$ versus the reciprocal of the $\mathrm{PG}$ concentration. The concentration of CDP-diacylglycerol was $0.10 \mathrm{mM}$ and the molar ratio of Triton X-100 to total phospholipid was maintained at $1: 1$. (B) the data are plotted as $1 / \mathrm{V}(\mathrm{U} / \mathrm{mg})$ versus the reciprocal of the CDP-diacylglycerol concentration. The concentration of PG was $0.50 \mathrm{mM}$ and the molar ratio of Triton X-100 to total phospholipid was maintained at $1: 1$. 


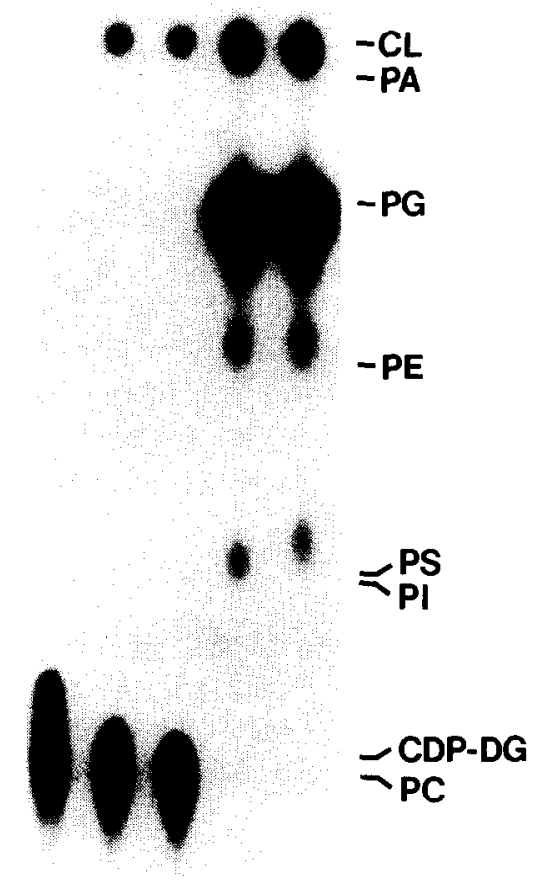

a b c d e

Fig. 7. Demonstration of CDP-diacylglycerol as a substrate for yeast CL synthase. ${ }^{32} \mathrm{P}$-labelled lipid products from a $\mathrm{CL}$ synthase reaction were extracted and separated by thin-layer chromatography in chloroform/methanol/acetic acid $(65: 25: 8, \mathrm{v} / \mathrm{v})$ in Lanes a-c, $\left[{ }^{32} \mathrm{P}\right] \mathrm{CDP}-$ diacylglycerol was used as the labelled substrate and in lanes $d$ and $e$, $\left[{ }^{32} \mathbf{P}\right] \mathrm{PG}$ was the labelled substrate. Lane a, 0 min incubation, lanes b-e, $20 \mathrm{~min}$ incubation. Phospholipid standards were visualized by Dittmer-Lester spray and are indicated at the right. CL, cardiolipin; PA, phosphatidic acid; PG, phosphatidylglycerol; PE, phosphatidylethanolamine; PS, phosphatidylserine; PI, phosphatidylinositol; CDP-DG, cytidine diphosphate diacylglycerol; PC, phosphatidylcholine.

cursor known to repress most of the enzymes involved in phospholipid biosynthesis in yeast [40]. Inositol had no effect on CL synthase activity, while PGP synthase activity was repressed in cells grown in the presence of inositol.

\section{Discussion}

We have demonstrated for the first time that CDPdiacylglycerol is a substrate in the yeast $\mathrm{CL}$ synthase reaction. When $\left[{ }^{32} \mathrm{P}\right] \mathrm{CDP}$-diacylglycerol labelled in the phosphatidyl moiety was incubated with mitochondrial extracts, the $C L$ product was labelled with ${ }^{32} \mathrm{P}$. This proves directly that CDP-diacylglycerol acts as a phosphatidyl donor for yeast CL synthase. In this regard, the yeast enzyme resembles more closely the mammalian enzyme [41] than the $E$. coli enzyme. In $E$. coli, while CDP-diacylglycerol is an activator of the enzyme, it is not a substrate [8].

The properties of yeast $\mathrm{CL}$ synthase are unique when compared to $\mathrm{CL}$ synthase characterized in other sys- tems. The optimal $\mathrm{pH}$ of 9.0 (Fig. 2) is much higher than that of 6.5-7.8 reported for the $E$. coli enzyme [42]. E. coli $\mathrm{CL}$ synthase is not affected by the addition of divalent cations or chelating agents, such as EDTA

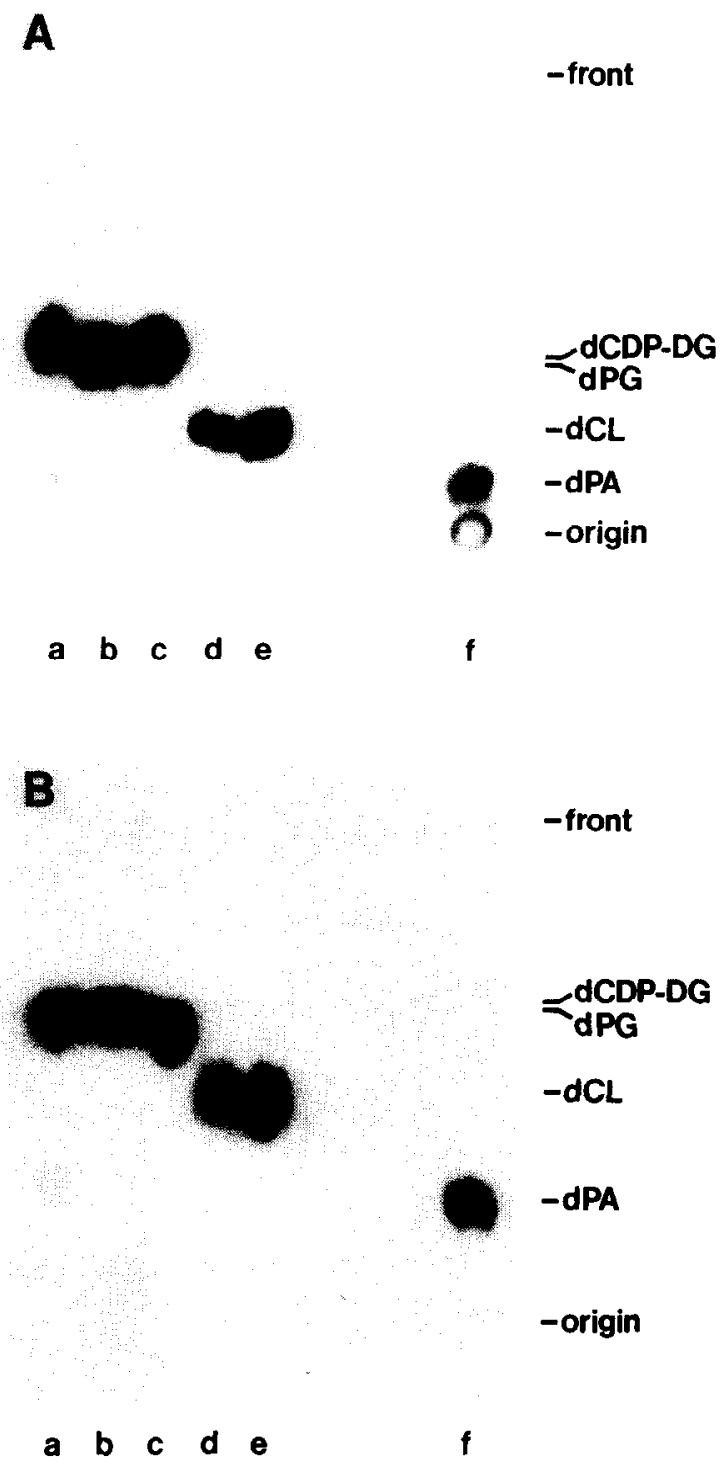

Fig. 8. Identification of ${ }^{32} \mathrm{P}$-labelled substrates and products from a $\mathrm{Cl}$ synthase reaction by mild alkaline hydrolysis. ${ }^{32} \mathrm{P}$-labelled lipids from a CL synthase reaction (from the experiment in Fig. 7) were scraped from a TLC plate and eluted with chloroform $/ 0.1 \mathrm{M} \mathrm{HCl}$ in methanol/water $(1: 1: 0.9, \mathrm{v} / \mathrm{v})$. Deacylation by mild alkaline hydrolysis was carried out as described. Deacylated samples and standards were spotted onto Whatman No. 1 paper and chromatographed in (A) isopropanol/water/ammonia $(7: 2: 1, \mathrm{v} / \mathrm{v})$ and (B) $1 \mathrm{M}$ ammonium acetate (pH 7.4)/absolute ethanol $(35: 65, \mathrm{v} / \mathrm{v})$. Deacylated phospholipid standards were visualized by Hanes-Isherwood spray (48) and their location indicated at the right. Lane a, deacylated $\left[{ }^{32}\right.$ P]CDP-diacylglycerol; lanes $b$ and $c$, deacylated $\left[{ }^{32} \mathrm{PJPG}\right.$; lane $d$, product from a $C L$ synthase reaction with [ ${ }^{32} \mathrm{PJCDP}$-diacylglycerol as the labelled substrate; lane e, product from a $\mathrm{CL}$ synthase reaction with $\left[{ }^{32} \mathrm{P}\right] \mathrm{PG}$ as the labelled substrate; lane $\mathrm{f}$, glycerol $3-\left[{ }^{32} \mathrm{P}\right]$ phosphate as a standard for deacylated PA. d, deacylated; CDP-DG, cytidine diphosphate diacylglycerol; PG, phosphatidylglycerol; CL, cardiolipin; PA. phosphatidic acid. 
[42]. In contrast, yeast CL synthase has a strict requirement for magnesium ions. Other divalent cations such as manganese, cobalt and calcium have little or no effect on activity (Fig. 3). The enzyme from rat and guinea pig liver mitochondria also requires divalent cations; however, cobalt, and to a lesser extent, manganese and magnesium all are effective in stimulating activity $[24,43]$. CL synthase activity is stimulated by the detergent Triton X-100 in both yeast and $E$. coli [42] while the enzyme from rat liver mitochondria is strongly inhibited by Triton X-100 [44]. Detailed kinetic analysis of CL synthase has not been carried out, although Tunaitis and Cronan reported saturation at concentrations as low as $3 \mu \mathrm{M}$ PG for the bacterial enzyme [42]. In rat and guinea pig liver mitochondria, apparent $K_{\mathrm{m}}$ values of $20 \mu \mathrm{M}$ and $1 \mu \mathrm{M}$ for PG and CDP-diacylglycerol, respectively, have been reported for CL synthase [24]. In contrast, our studies show much higher apparent $K_{\mathrm{m}}$ values for both PG and CDP-diacylglycerol of $1 \mathrm{mM}$ and $36 \mu \mathrm{M}$, respectively (Fig. 6). However, due to the inhibition of CL synthase activity by both substrates at high concentrations, it is difficult to interpret these values. Accurate determination of $K_{\mathrm{m}}$ values and analysis of substrate inhibition awaits purification of the enzyme, an eventual goal of our laboratory. The temperature optimum for $\mathrm{CL}$ synthase has not been reported in $E$. coli or in any mammalian sources. Yeast $\mathrm{CL}$ synthase activity was maximal at $45^{\circ} \mathrm{C}$ (Fig. 5A). Thermal stability of CL synthase is much greater than that of most phospholipid biosynthetic enzymes characterized in yeast $[29,45,46]$; more than $75 \%$ of its activity is retained at temperatures up to $55^{\circ} \mathrm{C}$ (Fig. 5B), whereas most phospholipid biosynthetic enzymes, except PI synthase [47] and PGP phosphatase [Kelly, B. and Greenberg, $M$., unpublished data] lose greater than $75 \%$ of their activity above $50^{\circ} \mathrm{C}$. Thermal stability of bacterial and mammalian $\mathrm{CL}$ synthase has not been ascertained.

Previously, we reported that the enzyme PGP synthase, the first enzyme in the CL biosynthetic pathway, is subject to cross pathway control along with the PI and PC branches, since the phospholipid precursor inositol was able to repress enzymes in all three pathways [30]. However, although PGP synthase was repressed in cells grown in inositol, this enzyme was under control by a different regulatory circuit since its activity was not affected by regulatory mutations known to affect the other pathways. In contrast, CL synthase expression is not affected by inositol. Additional experiments in our laboratory indicate that PGP phosphatase, like CL synthase, is not repressed in inositol-containing media [Kelly, B. and Greenberg, M., unpublished data]. These data suggest that the enzyme that catalyzes the committed step in CL synthesis is regulated differently from the subsequent two steps of the pathway.

The biochemical characterization of CL synthase lays the necessary groundwork for genetic and molecular studies to characterize the gene encoding this enzyme. These studies are currently in progress.

\section{Acknowledgements}

We are grateful to Dr. Christian Raetz for providing $E$. coli strain DH1/pCD100, Dr. Burton Tropp for $E$. coli strain HW 55 and Dr. William Dowhan for plasmid pPGL3008. We thank Drs. Amiya Hajra and Rowena Matthews for critically reading this manuscript and Catherine Smith and Ruby Hogue for assistance in preparation of this manuscript.

This work was supported by Public Health Service grant GM 37723 from the National Institutes of Health.

\section{References}

1 Pluschke, G., Hirota, Y. and Overath, P. (1978) J. Biol. Chem. 253, 5048-5055.

2 Daum, G. (1985) Biochim. Biophys. Acta 822, 1-42.

3 Sperka-Gottlieb, C.D.M., Hermetter, A., Paltauf, F. and Daum, G. (1988) Biochim. Biophys. Acta 946, 227-234.

4 Sekimizu, K. and Kornberg, A. (1988) J. Biol. Chem. 263, 71317135.

5 Sekimizu, K., Yung, B.Y. and Kornberg, A. (1988) J. Biol. Chem. $263,7136-7140$.

6 Yung, B.Y. and Kornberg, A. (1988) Proc. Natl. Acad. Sci. USA $85,7202-7205$.

7 Trivedi, A., Schwab, M., Fantin, D. and Tustanoff, E.R. (1987) in Membrane Receptors, Dynamics, and Energetics (Wirtz, K.W.A., ed.), pp. 319-328, Plenum Publishing, New York.

8 Trivedi, A., Wearring, A.V., Kohlwein, S.D., Paltauf, F. and Tustanoff, E.R. (1988) in Integration of Mitochondrial Function (Lemasters, J.J., Hackenbrock, C.R., Thurman, R.G. and Weterhoff, H.V., eds.), pp. 87-94, Plenum Publishing, New York.

9 Eilers, M., Endo, T. and Schatz, G. (1989) J. Biol. Chem. 264, 2945-2950.

10 Endo, T., Eilers, M. and Schatz, G. (1989) J. Biol. Chem. 264, 2951-2956.

11 Lambeth, J.D. (1981) J. Biol. Chem. 256, 4757-4762.

12 Pembert, S.O., Powell, G.L. and Lambeth, J.D. (1983) J. Biol. Chem. 258, 3198-3206.

13 Cobon, G.S., Crowfoot, P.D. and Linnane, A.W, (1974) Biochem. J. 144, 265-275.

14 Steiner, M.R. and Lester, R.L. (1972) Biochim. Biophys. Acta 260, 222-243.

15 Van den Bosch, H., Van Golde, L.M.G. and Van Deenen, L.L.M. (1972) Rev. Physiol. Biochem. Exp. Pharmacol. 66, 13-145.

16 Moore, T.S. (1982) Annu. Rev. Plant Physiol. 33, 235-259.

17 Hirschberg, C.B. and Kennedy, E.P. (1972) Proc. Natl. Acad. Sci. USA 69, 648-651.

18 Ohta, A., Obara, T., Asami, Y. and Shibuya, I. (1985) J. Bacteriol. $163,506-514$.

19 Nishijima, S., Asami, Y., Uetake, N., Yamagoe, S., Ohta, A. and Shibuya, I. (1988) J. Bacteriol. 170, 775-780.

20 Heacock, P.N. and Dowhan, W. (1987) J. Biol. Chem. 262, 13044 13049.

21 Heacock, P.N. and Dowhan, W. (1989) J. Biol. Chem. 264, 14972 14977.

22 McMurray, W.C. and Jarvis, E.C. (1978) Can. J. Biochem. 56, 414-419. 
23 MacDonald, P.M. and McMurray, W.C. (1980) Biochim. Biophys. Acta $620,80-89$.

24 McMurray, W.C. and Jarvis, E.C. (1980) Can. J. Biochem. 58, $771-776$.

25 Sparrow, C.P. and Raetz, C.R.H. (1985) J. Biol. Chem. 260 , 12084-12091.

26 Hwang, Y.W., Engel, R. and Tropp, B.E. (1984) J. Bacteriol. 157, $846-856$.

27 Tucker, S.D., Gopalakrishnan, A.S., Bollinger, R., Dowhan, W. and Murgola, E.J. (1982) J. Bacteriol. 152, 773-779.

28 Culbertson, M.R. and Henry, S.A. (1975) Genetics 80, 23-40.

29 Carman, G.M. and Belunis, C.J. (1983) Can. J. Biochem. 29, $1462-1457$.

30 Greenberg, M.L., Hubbell, S. and Lam, C. (1988) Mol. Cell. Biol. 8, 4773-4779.

31 Nichols, B.W. (1963) Biochim. Biophys. Acta 70, 417-422.

32 Walsh, J.P. and Bell, R.M. (1986) 261, 6239-6247.

33 Ohta, A., Waggoner, K., Radominska-Pyrek, A. and Dowhan, W. (1981) J. Bacteriol. 147, 552-562.

34 Raheja, R.K., Kaur, C., Singh, A. and Bhatia, I.S. (1973) J. Lipid Res. 14, 695-697.
35 Bradford, M.M. (1976) Anal. Biochem. 72, 248-254.

36 Davidson, J.B. and Stanacev, N.Z. (1970) Can. J. Biochem. 48. 633-642.

37 Ames, G.F. (1968) J. Bacteriol. 95, 833-843.

38 Chang, Y.Y. and Kennedy, E.P. (1967) J. Lipid Res. 8, 447-455.

39 Hanes, C.S. and Isherwood, F.A. (1949) Nature 164, 1107-1112.

40 Carman, G.M. and Henry, S.A. (1989) Annu. Rev. Biochem. 58 . 635-669.

41 Hostetler, K.Y., Van den Bosch, H. and Van Deenan, L.L.M. (1972) Biochim. Biophys. Acta 260, 507-513.

42 Tunaitis, E. and Cronan, Jr., J.E. (1973) Arch. Biochem. Biophys. $155,420-427$.

43 Hostetler, H.Y., Galesloot, P.B. and Van den Bosch, H. (1975) Biochim. Biophys. Acta 380, 382-389

44 Hostetler, K.Y. and Van den Bosch, H. (1972) Biochim. Biophys. Acta 260, 380-386

45 Bae-Lee, M.S. and Carman, G.M. (1984) J. Biol. Chem. 259, 10857-10862.

46 Kellcy, M.J. and Carman, G.M. (1987) J. Biol. Chcm. 262, $14563-$ 14570.

47 Fischl, A.S. and Carman, G.M. (1983) J. Bacteriol. 154, 304-311. 